\title{
TAXATION OF AGRICULTURAL AND FOREST LAND: COMPARATIVE PERSPECTIVE AND PRACTICE IN SERBIA
}

\author{
Dušan Vasiljević ${ }^{1}$
}

\section{Summary}

This paper discusses contradiction between theoretical preferences for using land as an object of taxation and modest revenues collected through property taxes imposed on agricultural and forest land. The paper starts with a summary of specificities of the land as an object of the property tax; then, classical economists' preferences for the wide use of the land tax are confronted with the comparative research finding numerous examples of exemptions and favorable treatment enjoyed by agricultural and forest land.

The second part of the paper builds on a database of average square meter prices of agricultural and forest land determined by local governments for fiscal years 2014 and 2015. The quantitative research provides evidences of inconsistency and volatility of land value assessments at significantly higher level than we find for structures, indicating that key principles of tax equity are undermined, placing disproportionately high burden on certain categories of land owners.

Keywords: agricultural land, forest land, property tax, property assessment, land valuation.

JEL: H21, N50, Q15

\section{Introduction}

Land is the most commonly used basis of the property tax. There are systems that apply property taxes on land only, but there is no case of a system that taxes structures (objects) and not the land. Our goal is to examine advantages and disadvantages of land taxation in general and to assess the practice of agricultural and forest land taxation in Serbia.

Land has one defining characteristic that sets it apart from other types of property tax bases: that is its fixed supply. With some negligible exceptions, land cannot be produced, nor destroyed. This fixed supply of land has profound implications, primarily in the sense of the tax incidence (meaning who effectively bears the burden of a tax). Rosen and Gayer used following two graphs to present difference in the property tax incidence between the land

1 Dušan Vasiljević, M.A., PhD candidate, US AID Business Enabling Project: Director for Business Regulation and Economic Governance; University of Singidunum, Faculty of Economics, Finances and Administration, Francuska street no. 6, 11000 Belgrade, Serbia, Phone: +381 6013000 18, E-mail: dvasiljevic@,bep.rs

EP 2016 (63) 2 (713-726) 
and structure. Key underlining concept behind those graphs is that supply of land is near perfectly inelastic, while supply of structures (objects) is near perfectly elastic. The later part of the concept is based on an assumption that structures are just one of many alternative uses of the capital. If a particular use of the capital (investment in structures) became more costly, the rational market participants would invest their capital in alternative uses, keeping the supply downside.

Figure 1. Incidence of the tax on land

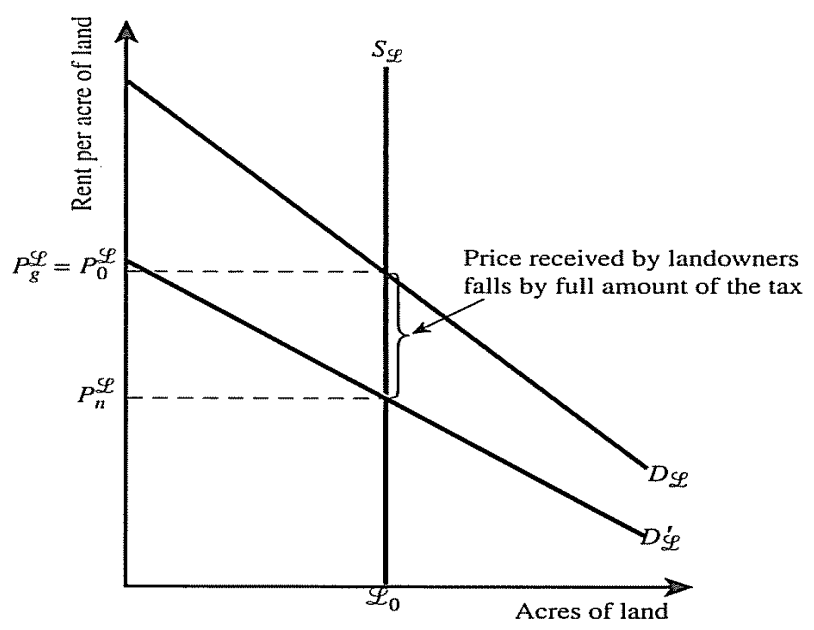

Source: Rosen, Gayer, 2008.

Figure 2. Incidence of the tax on structures

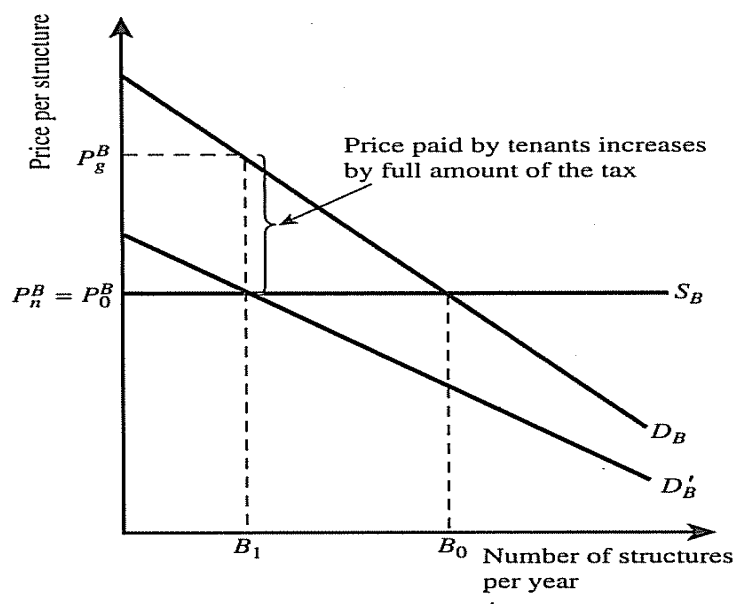

Source: Rosen, Gayer, 2008. 
These graphs show that full burden of the introduction of the property tax on the land, its supply being near perfectly inelastic (vertical line on the Figure 1), is borne by owners of the land, while users (renters) of the land do not feel consequences of the introduction of the tax ${ }^{2}$. Conversely, full burden of the introduction of the property tax on structures, whose supply is perfectly elastic (horizontal line on the Figure 2), is borne by renters of structures, even if owners are legally responsible for paying the tax. Owners of structures simply pass on the tax amount to renters, as any reduction in demand would be offset by capital outflow from construction to other uses, resulting in the same compensation that owners of the structures would receive from tenants, everything else being equal. However, those who bear the burden are not necessarily owners of the land at the moment of the payment of the property tax, but the owners at the moment when the tax was introduced, or when its introduction became imminent and widely known fact. From the moment of introduction, or credible announcement of the tax, all future payments of the property tax are capitalized in the value of the land, reducing what can be received for the sale of the land in the open market.

The key tax-related quality of the land is that taxing it does not change economic incentives of taxpayers, as their response to the tax cannot be to produce less land. Thus, low or no deadweight burden of the land tax is one of its key features. Together with the fact that land cannot be moved from one tax jurisdiction to another and that cannot be concealed, its fixed supply makes the land an ideal property tax base.

\section{Materials and methods}

Key methods used in the research are method of quantitative statistical analysis and the method of normative analysis of land taxation policy in Serbia. The basis for the research is the Standing Conference of Towns and Municipalities' (Kahn, 2001) (national association of local governments in Serbia) database of municipal ordinances on base prices of different types of properties for fiscal years 2014 and 2015. The database includes ordinances from 138 cities and municipalities - a vast majority of the total of 145 units of local self-government in Serbia, making it by far the most complete database of this kind. For analytical purposes, we have divided all local governments into municipalities (118), cities (19) and City of Belgrade. Our approach in analyzing the database was to compare results obtained for agriculture and forest land with results obtained for other types of properties, and particularly for the construction land and apartments. We compared results on several aspects: dispersion of data within the same property type and the same zone between different local governments; difference between base prices of properties defined for 2015 with values determined for fiscal 2015; differences in determined prices between different zones for the same types of properties.

2 Kahn holds that the tax on land can be shifted to tenants or lessees if (i) the land market is not competitive; (ii) the supply of land is relatively limited; and (iii) the tenants and workers are not well organized.

EP 2016 (63) 2 (713-726) 
Other sources of data include the Ministry of Finance's Treasury Administration data on public sector revenues and of the Republic Statistics Office's data on the gross domestic product.

\section{Taxation of agricultural and forest land: theoretical foundations and comparative practice}

Unique qualities of the land as a tax basis gave rise to the schools of political economy that argued that there should be only one tax - tax on the land. Sources of this concept can be traced back to John Locke and later on to the French physiocrats, which believed that all wealth is primarily derived from the agriculture and advocated introduction of the impot unique - the single tax on land. David Ricardo famously developed the concept of Ricardian rent, as a difference between productive potential of the land and productive potential of the best freely available land (Hollander, 1895). Tax implications of this concept are fundamental: Ricardian rent could be taxed with up to $100 \%$ rate, and owners still would not have an incentive to change the purpose of the land.

"The land-tax-only utopia" has limited policy applicability, but it helps us grasp vast underutilized importance of the land in most public finance systems. Henry George's intentions when putting forward suggestion of a single tax in his 1879's "Progress and Poverty" were to relieve labor and capital from taxation burden (George, 1935). His argument was that value of the land is at least determined by its owner's action, as it mostly depends on natural characteristics (mostly relevant for agricultural land) or actions of the rest of society, such as access to infrastructure or proximity to costumers (most relevant in the case of construction land). Currently, one of the prevailing arguments in favor of land tax is that such tax reduces speculation with the land and motivates owners to put it into most productive use. Ethics of land taxation is traditionally one of fundamental considerations in relation with this tax, often influenced by the views of the land rent as an unearned income (Brown, 1917).

Land tax has an effect of reducing its market value, making it more affordable to potential investors. Result of a simulation of a revenue neutral replacement of the property tax with the land tax (meaning exempting the improvements on the land) show increase in both total employment and gross state product indicators (England, 2003).

Land value fundamentals consist of four components: a) the agricultural land value, as the capitalized value of the agricultural rent stream, b) the value of expected rent increases caused by population growth, c) value of accessibility to the city center, and d) the cost of development conversion, capturing the investment in capital improvements to the land (Anderson, 2012). Tax burden influence on the land value must take into consideration combined tax reliefs, which were in the US estimated to pay for $80-90 \%$ of farmers' property taxes and raise land values by almost 10\% (Anderson, Bunch, 1989).

One of the key principles in assessment activities is that properties are valued in accordance with its best and highest use, regardless of the fact that current use might be different. However, agricultural land is granted an exemption from this rule in many tax systems. For example, in most of federal states of the USA, there is a requirement to assess the agricultural land based 
on its current use (Bell at al., 2009). Reason for this policy is twofold: social aspect intends to provide a relief to often poor farmer families that use as agricultural land parcels that are designated for development (and therefore significantly more expensive); environmental aspect is reflected in the policy that favors use of the land in a manner that has smaller environmental footprint. Although widely used, the policy of assessing the agricultural and forest land based on its current use has some drawbacks - firstly, it discourages using the land in its most productive use, thus reducing the benefits for overall society; secondly, it incentivizes using the land for speculative purposes.

Agricultural land is exempt from taxation in many property tax systems. Reasons for that are similar as ones we presented in relation with the mandate to assess the agricultural land in accordance with its current use - combination of social and environmental considerations. However, there is another reason, which stems from the very nature of the property tax. Its key purpose is to generate necessary revenues for maintaining local infrastructure and providing municipal services. Given the fact that agricultural land is often completely neglected in terms of municipal infrastructure and that it is a negligible consumer of local government services compared with construction land and structures, there are arguments that it should not be taxed at all. Counterarguments point out to locally financed systems and services that are less visible, but still important for the use of agricultural land - anti-hail systems, local roads, melioration systems, local police etc.

Systems with partial exemptions or different methods of providing preferential treatment to the agricultural land are numerous: in France, agricultural properties are exempt from the land and building tax; in Germany, agricultural land values are not indexed, thus resulting in effective tax rates being significantly below other types of properties; in Hungary, land plots below municipality-determined thresholds are exempt; in Ireland, agricultural land is exempt as a result of a court decision; in Italy, rural properties are exempt from the tax on immovable property; in the Netherlands, agricultural (including horticultural) land is exempt from the municipal tax (but not from contributions to polder boards); the properties of agricultural enterprises are exempt in Russia; in United Kingdom, agricultural land are exempt; in Estonia agricultural lands is valued on the profits basis (UN Habitat, 2013); in Ontario, Canada, the farm tax rate is set by provincial law at only $25 \%$ of the residential tax rate (Slack, Bird, 2014).

Exemptions applicable on agricultural land are usually applied on forest land as well, mostly on the grounds of the same argument. However, the forest land has its particular set of considerations when it comes to the question whether it should be subject of property taxation. Value of the forest land itself, when the value of standing timber is excluded, is rather low. Additionally, owners of the forest land need to pay property tax for number of years before being able to raise any income by harvesting the timber.

The broad scope of exemptions related with agricultural and forest land appears to be in contradiction with earlier considerations of the land tax as an almost ideal tax. Skinner addresses this contradiction in a paper of a very telling title (Skinner, 1991):

a) Current landowners object to land taxation because the tax capitalizes in the form of 
reduction of the land value.

b) The land tax does not accommodate for the risks of agricultural production. The land tax must be paid annually, even if the year was so bad that not even the investment costs were recovered.

c) Thirdly, the land tax is administratively very challenging. Costs of inventorying the land, assessing it, producing the tax bill and collection are high compared with other taxes.

Other researcher point out to additional issues with the land tax, including the difficulty to determine the value of land net of improvements (Cohen, Coughlin, 2005). With these considerations in mind, we move to the current practice of taxation of agricultural and forest land in Serbia.

\section{Taxing the agricultural and forest land in Serbia - key features}

Annual property tax is own source revenue of local governments, which means that cities and municipalities set the tax rates, within limits established by the law, and receive all yields of the tax. Local governments also administer the tax: decide on zoning for property tax purposes, determine average square meter prices of different types of properties, assess the properties, send out tax bills and collect the tax.

Importance of the property tax for cities and municipalities increased significantly in recent years: from $7.6 \%$ of total local government revenues in 2013 to $14.1 \%$ in 2015 . However, level of land tax revenues remains rather very modest.

Table 1. Importance of the land tax in the public finance system

\begin{tabular}{|l|c|c|c|c|c|}
\hline & Year 2009 & Year 2010 & Year 2011 & Year 2012 & Year 2013 \\
\hline Land tax & 835,218 & 979,715 & $1,124,211$ & $1,189,314$ & $1,256,118$ \\
\hline $\begin{array}{l}\text { Land tax share in the } \\
\text { property tax (\%) }\end{array}$ & 5.0 & 4.9 & 5.3 & 5.4 & 5.3 \\
\hline $\begin{array}{l}\text { Property tax share in } \\
\text { GDP (\%) }\end{array}$ & 0.58 & 0.65 & 0.62 & 0.61 & 0.61 \\
\hline
\end{tabular}

Source: Author's calculations based on Treasury Administration data on revenues and Republic Statistics Office's GDP data;

Note: revenue data are in thousands of RSD

Property tax is imposed on owners and holders of the usage rights on the land, but not on holders of the leases. In 2012, out of 2,480 million hectares of agricultural land enlisted in the Register of Agricultural Holdings, 773,603 hectares was leased land, out of which $40 \%$ is publicly owned agricultural land (Cvjetković et al., 2015). That means that more than $12 \%$ of land enlisted in the Register of Agricultural Holdings is tax exempted.

Land in Serbia is object of property taxation if its area exceeds 10 ares. If land area is 12 ares, not only 2 ares will be taxed, but all 12 ares. If a land is designated as a construction (urban) land in the spatial or zoning plans, but it is used as agricultural land, for the purpose of 
property taxation it will be treated as construction land, and therefore subject of higher taxes. This is an important deviation from the widespread practice to assess the agricultural land in accordance with its current use.

The legislation provides a partial exemption for the land that is being re-used as agricultural or forest land, during five years following conversion to that types of use. Another exemption benefits large number of potential and tax payers: for properties valued below 400,000 RSD (approximately EUR 3,300). However, this exemption is applicable only if all properties of a tax payer on the territory of one municipality fall below this threshold. For a payer who owns a house, however modest, and a piece of land, this exemption most likely will not be applicable. Consequently, this exemption is more likely to benefit an owner who resides in one municipality and owns (often by inheritance) a land in another municipality - exactly the category of owners that prudent policy would not intend to protect from property taxes.

With regards to the land tax rates, land is favored in two ways: maximum tax rate for land is $0.3 \%$, while for other types of properties can be up to $0.4 \%$; additionally, structures can be object of progressive tax rates for values assessed at more than 10 million RSD, with rates going up to the level of as much as $2 \%$. For the land, however, no progressive rates are allowed.

Serbia has legislated in 2013 (Official Gazette of the Republic of Serbia”, no. 47/2013) a comprehensive reform of assessment methodology for the property tax purposes. Most profound changes were implemented in the segment of land valuation. Cadaster value of the land was finally abolished as a basis for the property tax on agricultural and forest land. ${ }^{3}$ Two models of land value assessment were introduced, depending on the type of tax payer. For businesses that keep books in accordance with international accounting standards, basis of the property tax is value of the property as recorded in company's books; for all other payers, the value of land is determined by multiplying area of the land and the average price of the given type of property in a given zone. Next, we focus on the method of assessment of the land value for tax payers that do not keep books in accordance with the international accounting standards, as this is by far bigger share of the total number of land tax payers.

\section{System of zones for determining average property prices}

For the property assessment purposes, the key concept is the average price of the given type of property in a given zone. Each type of property is assigned its own average price in a given zone. That means that different average prices are determined for agricultural and for forest land. Average prices are determined by zones. Each local government has to define at least two zones, which are the same for all types of properties.

As the Table 2 shows, the second zone is the one where majority of local governments determine average prices of both agricultural and forest land, followed by the first zone. More municipalities have determined average prices of agricultural and forest land in first

3 This reform was long overdue. Cadaster values have not been updated for many years, producing assessments that have been only a fraction of the market value of the land.

EP 2016 (63) 2 (713-726) 
than in third zone. It can be explained by a fact that number of municipalities exercised its legal right to determine only two zones. As the column "Total" shows, municipalities have much less frequently determine average prices for agriculture land and forest land per zones (247 and 191 instances respectively) than for other types of properties. Expectedly, more municipalities have determined average prices of agricultural land, than the forest land. However, it was unexpected to find out that three municipalities have agricultural land and two have forest land in their extra zones.

Table 2. Number of municipalities that determined specific zones for the 2015 fiscal year

\begin{tabular}{|l|c|c|c|c|c|c|c|}
\hline & Extra zone & I Zone & II Zone & III Zone & IV Zone & V Zone & Total \\
\hline Construction land & 7 & 104 & 100 & 41 & 42 & 15 & 309 \\
\hline Houses & 7 & 112 & 104 & 47 & 42 & 14 & 326 \\
\hline Apartments & 7 & 118 & 98 & 44 & 38 & 10 & 315 \\
\hline Business premises & 8 & 112 & 101 & 44 & 44 & 13 & 322 \\
\hline Agricultural land & 3 & 65 & 81 & 36 & 44 & 18 & 247 \\
\hline Forest land & 2 & 48 & 61 & 26 & 38 & 16 & 191 \\
\hline Total $^{1}$ & 41 & 668 & 644 & 280 & 289 & 98 & 2,020 \\
\hline
\end{tabular}

Source: Database of the Standing Conference of Towns and Municipalities and author's calculations

In cities, situation is somewhat different than in municipalities, primarily because cities tend to define larger number of zones on their territories: most cities determined average prices of agricultural land in the Zone IV (16 cities), followed by Zone III (13) and Zone II (9); for forest land, Zone IV is also the leading one (11 cities), followed by Zones II and III (9 cities).

\section{Determination of average prices of the agricultural and forest land}

The Law on Property Taxes envisages that average prices per zones, differentiated between seven types of properties, should be determined based on the transactional data originated in the period of January-September preceding the year for which the average prices are determined. At least three transactions are required for each type of property for each zone. If there are no data on at least three transactions, calculation for that type of property is made based on average prices in neighboring zones that have records of three or more transactions - regardless of the fact whether those zones are in the same or a different local government.

Table 3. Key findings in relation with the average prices of agricultural land in municipalities

\begin{tabular}{|l|c|c|c|c|c|c|}
\hline & $\begin{array}{c}\text { Extra } \\
\text { zone }\end{array}$ & I Zone & II Zone & $\begin{array}{c}\text { III } \\
\text { Zone }\end{array}$ & IV Zone & $\begin{array}{c}\text { V } \\
\text { Zone }\end{array}$ \\
\hline $\begin{array}{l}\text { Number of municipalities that determined } \\
\text { average price for 2015 }\end{array}$ & 3 & 65 & 81 & 36 & 44 & 18 \\
\hline Lowest average price for 2015 & 60 & 10 & 9 & 10 & 4 & 8 \\
\hline
\end{tabular}




\begin{tabular}{|l|c|c|c|c|c|c|}
\hline Highest average price for 2015 & 137 & 2,319 & 909 & 868 & 529 & 137 \\
\hline Average price for 2015 & 90 & 131 & 90 & 79 & 152 & 46 \\
\hline Ratio of average prices 2015/2014 & 1.16 & 1.85 & 1.03 & 1.08 & 2.23 & 0.87 \\
\hline Ratio of average prices in 2015/14 above 2 (\%) & 0 & 7 & 12 & 0 & 0 & 0 \\
\hline Ratio of average prices in 2015/14 below 0.5 (\%) & 0 & 0 & 2 & 3 & 9 & 0 \\
\hline
\end{tabular}

Source: Database of the Standing Conference of Towns and Municipalities and author's calculations Note: prices are in $\mathrm{RSD} / \mathrm{m}^{2}$

One of the key findings based on the analysis of the administratively set average prices of agricultural land in municipalities is that average prices for 2015 per different zones show no consistency. As seen in the Table 3, average prices for 2015 are highest in the zone IV, followed by the zone I. The lowest prices are in the zone V. Ratio between the averages for the fourth and fifth zone are more than 1 to 3. Difference between highest and lowest prices determined for a whole zone is staggering: from 4 to 2,319 RSD per square meter of agricultural land (1:780 ratio). It is difficult to assume that difference in productivity of the land could account for such a difference in assessed value of the land. Example of Bajina Basta municipality is rather illustrative: price for the zone I and zone II of 462 RSD determined for the year 2015 is more than 12 times higher compared to 2014 prices in the zone II and almost 9 times more than price determined for the neighboring zone III for the same year 2015.

Next, we went another level deeper in our analysis and compared average prices of agricultural land per zones determined in 2015 with average prices determined by same municipalities for same zones in 2014, looking for major increases or decreases, only to find even more worrying evidences. As many as $12 \%$ of municipalities more than doubled prices in their zones II, and 7\% of municipalities did the same in the zone II. Significantly lesser number of local governments made a similar move in opposite direction, by more than halving prices in 2015 compared with 2014 - most of them for the zone II: $9 \%$ of all municipalities. Volatility is visible in the ratio of averages of prices set by local governments in 2015 versus 2014: in zone I prices in 2015 are almost double that from 2014 and in zone II prices are more than double than just a year ago. Needless to say, there were no market reasons that would justify any similar changes in prices of the land in just a year's time, so the only explanation is that different values are direct result of administrative decisions based on the legal framework for land assessment.

Situation in cities is rather similar in terms of inconsistency and volatility of land values assessments, only perhaps more radical. While $9 \%$ of prices per zones between 2014 and 2015 in municipalities were radically changed (increased by more than double or decreased by a half at least), that share in cities was $17.5 \%$. Example of the City of Kraljevo is illustrative in terms of volatility of the land value assessments. Kraljevo for the zone I did not determine the average prices for 2015, while for the zone II determined price of 86 RSD (almost five time less than the value determined for the same zone for 2014); the price for zone III is almost double (192), only to fall to the level of 47 RSD in the zone IV. 
City of Belgrade also features an interesting practice in terms of land assessment. Highest prices determined for fiscal 2015 are $750 \mathrm{RSD} / \mathrm{m}^{2}$, in four out of its 14 zones. Those prices in the four zones are only a third of the values determined for the previous year. Ratio of prices for 2015 compared with those determined for 2014 are in the scope between 0.26 and 1.47. Volatility of land assessments in the City of Belgrade is well illustrated by the fact that prices in six out of 14 zones got reduced by more than a half in just a year period, without any significant development on the land market.

The forest land data on property tax follows similar patterns as the agricultural land does. Difference between lowest and highest price determined per zones in municipalities goes between 4.34 and $250 \mathrm{RSD} / \mathrm{m}^{2}$, which is 1:55 ratio - hardly a difference that productivity of the forest land can account for. Average prices per zones are more consistent, spanning from 46 dinars in the zone III to 60 RSD in the zone I.

Table 4. Key findings in relation with the average prices of forest land in municipalities

\begin{tabular}{|l|c|c|c|c|c|c|}
\hline & Extra zone & Zone I & Zone II & $\begin{array}{c}\text { Zone } \\
\text { III }\end{array}$ & Zone IV & Zone V \\
\hline Lowest price 2015 & 30.00 & 9.95 & 9.95 & 10 & 4.34 & 7.11 \\
\hline Highest price in 2015 & 75.00 & 240 & 206 & 206 & 137 & 200 \\
\hline Average price in 2015 & 53 & 60 & 50 & 46 & 47 & 49 \\
\hline Average price 2015/2014 & 0.90 & 1.40 & 1.22 & 0.92 & 1.23 & 0.96 \\
\hline Share of 2015/14 above 2 (\%) & 0 & 6 & 7 & 4 & 16 & 13 \\
\hline Share of 2015/14 below 0.5 (\%) & 0 & 0 & 4 & 7 & 5 & 13 \\
\hline
\end{tabular}

Source: Database of the Standing Conference of Towns and Municipalities and author's calculations; Note: prices are in $\mathrm{RSD} / \mathrm{m}^{2}$

Changes in prices between 2014 and 2015 are excessive by any account. For Zone IV, as many as $16 \%$ of municipalities have determined for 2015 prices that are at least double than the 2014 prices. For the zone V, 13\% of municipalities for 2015 reduced prices of the forest land by more than a half. Database shows evidence of the municipalities increasing prices between 2014 and 2015 by more than 8 times and others reducing prices by almost $90 \%$.

Findings regarding forest land are similar in cities as well. There were drastic changes between 2014 and 2015 with regards to prices determined by local governments in $30 \%$ of all cases, while that share was $13 \%$ in the case of municipalities. Cases of individual cities also exhibit lack of consistency: for the zone I prices, we found that Novi Pazar had a value of 1,960 RSD, Smederevo 125 RSD, Cacak 70 RSD and Sabac 42 RSD. Even within same city, we found evidences of differences that are difficult to explain in economic terms: price of forest land in Novi Pazar was set at the level of 73 RSD in the zone VI, and 1,120 RSD/m² in the zone II.

For the forest land, City of Belgrade has followed same pattern as for agricultural land and determined highest price (700 RSD/m²) in four out of 14 zones, and lowest price (of $70 \mathrm{RSD} /$ $\mathrm{m}^{2}$ ) in the zone VIII; also, prices in four most expensive zones have been reduced for 2015 
by two thirds compared with 2014 levels. In other zones, ratio between 2015 and 2014 prices span from 0.26 to 1.20 , against all expectations that could be grounded on market tendencies.

Table 5 provides additional evidence on the lack of reliability of the agricultural land valuations by comparing coefficients of variation $(\mathrm{CoV})^{4}$ for all prices of the agricultural land determined by local governments, per zones, with that of apartments ${ }^{5}$.

Table 5. Coefficients of variation of prices per zones for selected types of properties

\begin{tabular}{|l|l|c|c|c|c|c|c|}
\hline & & $\begin{array}{c}\text { Extra } \\
\text { zone }\end{array}$ & Zone I & Zone II & Zone III & Zone IV & Zone V \\
\hline \multirow{2}{*}{ Apartments } & Municipalities & 0.53 & 0.51 & 0.44 & 0.49 & 0.52 & 0.55 \\
\cline { 2 - 8 } & Cities & 0.16 & 0.22 & 0.22 & 0.27 & 0.46 & 0.50 \\
\hline \multirow{2}{*}{$\begin{array}{l}\text { Agricultural } \\
\text { land }\end{array}$} & Municipalities & 0.37 & 2.32 & 1.59 & 1.61 & 4.36 & 0.71 \\
\cline { 2 - 8 } & Cities & - & 1.66 & 2.10 & 2.35 & 2.36 & 0.36 \\
\hline
\end{tabular}

Source: Database of the Standing Conference of Towns and Municipalities and author's calculations

As the Table 5 shows, CoV values for agricultural land are rather excessive compared with the apartments. All CoV values for the apartments fall in the interval between 0.16 and 0.55 ; at the same time, all but three values for agricultural land are above the 1.5 level, going all the way up to 4.36. High levels of dispersion of the administratively determined prices of the agricultural land and volatility in the data series indicate systemic lack of reliability of assessed values.

What makes prices determined for agricultural and forest land so gravely unreliable compared with apartments? Primarily fewer transactions data are available for calculations of the average prices per a zone. As the case of apartments so effectively proves, central zones of both cities and municipalities, where traditionally most transactions are taking place, have lowest CoVs. Going towards the periphery, $\mathrm{CoV}$ values rise for both cities and municipalities, as those zones feature fewer transactions that could be used for calculations of averages. When it comes to agricultural land, we see that $\mathrm{CoV}$ values are rather high in all zones - because determination of average prices based on transactional data is hampered by insufficient number of transactions in all zones.

What is the result of the rule that prices per zones are determined based on calculation of average square meter value based on available transaction data in the context of limited number of available data? If less than three valid transactions are available, local government must seek transaction data from neighboring zones with three or more transactions. That puts land tax payers in disadvantageous position since zones that are likely to have more transactions are zones with more dynamic land market, and those are most often zones with

4 Coefficient of variation $(\mathrm{CoV})$ is widely used as a measure of the dispersion of a data series around the mean. Higher values of $\mathrm{CoV}$ indicate higher level of volatility in a data series.

5 Apartments were deliberately chosen for this comparison exercise as most transaction data are available for that type of property, making assessments based on transactional data for apartments most reliable among all types of property.

EP 2016 (63) 2 (713-726) 
higher prices than zones with stagnant market with few or no transactions. As a result, prices from higher-value zones with more transactions are being "copied" to lower-value zones.

Alternatively, a certain zone can have enough transaction data for the calculation of the average price of the land in a zone (it could be only three transactions). But such a system is also systemically flawed, as one transaction of a land that is untypical in the context of other land in the zone can "contaminate" the whole sample and predominately influence the average price. This syndrome of "outlier transaction" dominating final result is not just a theoretical possibility. Agricultural land that is most likely to be object of a transaction is either most attractive land in a zone or parcel that is expected to be rezoned to construction use. In most of the cases, owners of typical land are likely to be "victims" of more attractive land - either from higher value zones or from more desirable land parcels in the same zone.

\section{Conclusion and recommendations}

It has been often suggested, more in political economy literature than in public policy discourse, that land is an optimal tax base. The land is not mobile, it is not easily concealed, its supply is fixed and thus taxing does not result in decrease in production, so there are no deadweight costs. At the same time, agricultural and forest land in many comparative systems enjoy full or partial exemptions or otherwise preferential tax treatment - through lower tax rates, special assessment rules etc. This is primarily result of attempts to benefit large number of small properties' owners, who often make vulnerable categories of the society.

With the reform of property assessment rules for tax purposes in 2013, land taxation pendulum in Serbia has moved from the land being virtually untaxed to becoming arguably overtaxed. This paper presents evidence that legal framework for land taxation produces volatile and unreliable assessments for the agricultural and forest land, especially compared with other types of properties. Data on transactions of higher-value land in the same or neighboring zones artificially increases land value assessment for typical land in a given zone. These systemically flawed assessments undermine some key principles of tax equity, jeopardize the notion of equality of actors on the market and impose an excessive burden on tax payers - often particularly on the very categories of the population that other public policies aim to protect: the poor, elderly and rural families.

Based on presented findings, we believe that following changes to the property taxation system should be considered: abolishing determination of average prices for the agricultural land based on transactions in neighboring zones when not enough transactions data are available for the given zone; providing for an effective mechanism for owners of the agricultural land to challenge local tax administrations' assessments, possibly by making individual valuations of certified appraisers an evidence in the tax assessment process; assessing agricultural land that was re-zoned to the construction land use as the agricultural for five years, if used for agricultural production in that period; replacement of the forest tax with the charge on harvested timber. 


\section{Literature}

1. Anderson, J. (2012): Agricultural Use-Value Property Tax Assessment: Estimation and Policy Issues, Public Budgeting \& Finance, vol. 32, no. 4, pp. 71-94, Public Financial Publications, Inc,

2. Anderson, J., Bunch, H. (1989): Agricultural Property Tax Relief: Tax Credits, Tax Rates, and Land Values, Land Economics vol. 65, no. 1, University of Wisconsin Press, Wisconsin, USA.

3. Almy, R. (2014): Valuation and Assessment of Immovable Property, OECD Working Papers on Fiscal Federalism, No. 19, OECD Publishing, Paris, France, (available at: http://dx.doi.org/10.1787/5jz5pzvr28hk-en).

4. Arsić, M., Ranđelović, S., Bućić, A., Vasiljević, D. (2012): Reforme poreza na imovinu u Srbiji: Rezultati i perspektive, Fondacija za razvoj ekonomske nauke, Beograd, Srbija.

5. Begović, B., Bisić, M., Ilić-Popov, G., Mijatović, B., Popović, D. (2004): Reforma poreskog sistema (2), Centar za liberalno-demokratske studije, Beograd, Srbija.

6. Bell, M., Bowman, J., German, J. (2009): The Assessment Requirements for a Separate Tax on Land, in Land Value Taxation: Theory, Evidence, and Practice, ch. no 8, pp. 171194, Lincoln Institute of Land Policy, Cambridge, USA.

7. Brown, H. (1917): The Ethics of Land-Value Taxation, Journal of Political Economy, vol. 25, no. 5, pp. 464-492, The University of Chicago Press, Chicago, USA.

8. Cvjetković, C., Veselinović, J., Nikolić, I. (2015): Tax Treatement of Farmers in the Republic of Serbia, Economics of Agriculture 3/2015, Vol. 62, pp. 737-749, IEP, Belgrade, Serbia.

9. Cohen, J., Coughlin, C. (2005): An Introduction to Two-Rate Taxation of Land and Buildings, Federal Reserve Bank of St. Louis Review, May/June 2005, vol. 87, no. 3, pp. 359-74, Saint Louis, USA.

10. England, R. (2003): State and Local Impacts of a Revenue-Neutral Shift from a Uniform Property to a Land Value Tax: Results of a Simulation Study, Land Economics, vol. 79, no. 1, pp. 38-43, University of Wisconsin Press, Wisconsin, USA.

11. George, H. (1935): Progress and Poverty, Robert Schalkenbach Foundation, NewYork, USA.

12. Hollander, J. (1895): The Concept of Marginal Rent, The Quarterly Journal of Economics, vol. 9, no. 2, pp. 175-187, Oxford, United Kingdom.

13. Kahn, M. (2001): Agricultural taxation in developing countries: a survey of issues and policy, Agricultural Economics, vol. 24, pp. 315-328, Elsevier, Amsterdam, Netherlands.

14. McCluskey, W., Bell, M. (2008): Rental Value versus Capital Value: Alternative Bases for the Property Tax, International Studies Program Working Paper 08-18, Andrew Young School of Political Studies, Atlanta, USA.

15. Official Gazette of the Republic of Serbia, the Law on Property Taxes, no. 26/2001, 80/2002, 135/2004, 61/2007, 5/2009, 78/2011, 47/2013 and 68/2014.

16. Rosen, H., Gayer, T. (2008): Public Finance, McGraw-Hill/Irwin, New York, USA.

17. Skinner, J. (1991): If agricultural land taxation is so efficient, why is it so rarely used?, the World Bank economic review, vol. 5, no. 1 (January 1991), pp. 113-133, Washington, 
DC, USA.

18. Slack, E., R. Bird (2014): The Political Economy of Property Tax Reform, OECD Working Papers on Fiscal Federalism, no. 18, OECD Publishing, Paris, France (available at http://dx.doi.org/10.1787/5jz5pzvzv6r7-en).

19. Tiits, T. (2008): Land Taxation Reforms in Estonia, in Roy Bahl, ed., Making Property Tax Work, chapter no. 14, pp. 395-410, Lincoln Institute of Land Policy, Cambridge, USA2008.

20. United Nations Human Settlements Programme (UNHABITAT) (2013): Property Tax Regimes in Europe, Nairobi, Kenya.

21. Youngman, J. (2006): Legal Issues in Property Valuation and Taxation: Cases and Materials, Lincoln Institute of Land Policy, Cambridge, USA.

\title{
OPOREZIVANJE POLJOPRIVREDNOG I ŠUMSKOG ZEMLJIŠTA: KOMPARATIVNA PERSPEKTIVA I PRAKSA U SRBIJI
}

\section{Dušan Vasiljevićc}

\begin{abstract}
Sažetak
U ovom radu se razmatra kontradiktornost između teorijske sklonosti ka korišćenju zemljišta kao predmeta oporezivanja i relativno skromnih prihoda koji se ubiraju po osnovu poreza na poljoprivredno i šumsko zemljište. Izlaganje u radu počinjemo pregledom specifičnosti zemljišta kao predmeta oporezivanja; zatim preferencijama klasične ekonomske škole u pravcu šireg oslanjanja na porez na zemljište suprotstavljamo rezultate komparativnog istraživanja o brojnim oslobađanjima $i$ drugim poreskim pogodnostima koje uživaju poljoprivredno i šumsko zemljište.

Drugi deo rada se temelji na formiranoj bazi podataka o prosečnim cenama različitih vrsta nepokretnosti utvrđenih od strane lokalne samouprave za 2014. i 2015. godinu. Kvantitativno istraživanje pruža dokaze o postojanju nedoslednosti i sklonosti drastičnim odstupanjima kod procena vrednosti zemljišta, i to na značajno višem nivou nego kod objekata, ukazujući na podrivanje ključnih principa poreske jednakosti i neproporcionalno opterećenje poreskim obavezama pojedinih kategorija vlasnika zemljišta.
\end{abstract}

Ključne reči: poljoprivredno zemljište, šumsko zemljište, porez na imovinu, procena vrednosti nepokretnosti, vrednovanje zemljišta.

6 Dušan Vasiljević, magistar Fakulteta političkih nauka, doktorand, direktor za regulatorne reforme u privredi USAID Projekta za bolje uslove poslovanja; Univerzitet Singidunum, Fakultet za finansije, ekonomiju i administraciju, Francuska ulica br. 6, 1100 Beograd, Telefon: +381 6013000 18, E-mail: dvasiljevic@,bep.rs 